\title{
Antibacterial Attributes of Apigenin, Isolated from Portulaca oleracea $L$.
}

\author{
Hanumantappa B. Nayaka, Ramesh L. Londonkar, Madire K. Umesh, and Asha Tukappa \\ Department of Post Graduate Studies and Research in Biotechnology, Gulbarga University, Gulbarga, Karnataka 585106, India \\ Correspondence should be addressed to Ramesh L. Londonkar; londonkarramesh53@gmail.com
}

Received 29 November 2013; Revised 14 April 2014; Accepted 14 April 2014; Published 13 May 2014

Academic Editor: Gary Dykes

Copyright (C) 2014 Hanumantappa B. Nayaka et al. This is an open access article distributed under the Creative Commons Attribution License, which permits unrestricted use, distribution, and reproduction in any medium, provided the original work is properly cited.

\begin{abstract}
The flavonoid apigenin was isolated from aerial part of $P$. oleracea $L$. The dried sample of plant was powdered and subjected to soxhlet extractor by adding $80 \mathrm{~mL}$ of ethanol : water $(70: 30)$. The extract was centrifuged at $11000 \mathrm{rpm}$ for $30 \mathrm{~min}$; supernatant was taken for further use. The fraction was concentrated and subjected to PTLC. The $R_{f}$ value of isolated apigenin was calculated (0.82). Purified material was also subjected to its IR spectra, LC-MS, NMR, and HPLC for structural elucidation. The apigenin so-obtained was subjected to antibacterial activity on five pathogenic bacterial strains like Pseudomonas aeruginosa, Salmonella typhimurium, Proteus mirabilis, Klebsiella pneumoniae and Enterobacter aerogenes; among all the bacterial strains, Salmonella typhimurium (17.36 \pm 0.18 ) and Proteus mirabilis (19.12 \pm 0.01 ) have shown maximum diameter of inhibition zone for flavonoid and remaining bacterial strains have shown moderate diameter of inhibition zone when compared with control values $14.56 \pm 0.21$ and $11.68 \pm 0.13$, respectively. The minimum inhibitory concentration (MIC) of the flavonoid isolated from P. oleracea L. was tested at the concentration ranging from undiluted sample to $10 \mathrm{mg}$ per $\mathrm{mL}$ of concentration. The minimum inhibition concentration (MIC) for the flavonoid for all tested bacterial strains was found to be $>4 \mathrm{mg}$ per $\mathrm{mL}$. Hence, the apigenin has antibacterial property and can be used to develop antibacterial drugs.
\end{abstract}

\section{Introduction}

Plants have potent biochemical components which are phytomedicine. Plant based natural constituents can be derived from any part of the plant like bark, leaves, flowers, roots, fruits, seeds, and so forth, and used as medicine by the man since the time immemorial [1]. The beneficial medicinal effects of plant materials are typically the result of combinations of secondary products present in the plant. The medicinal values of plants are unique to particular plant species or groups and are consistent with this concept as the combination of secondary products in a particular plant is taxonomically distinct [2]. Flavonoids are group of about 4000 naturally occurring polyphenol compounds, found universally in all the plants [3]. These are primarily recognized as the pigments responsible for the colors of leaves, especially in autumn. Flavonoids are widely distributed in fruits, vegetables, nuts, seeds, herbs, spices, stems, and flowers as well as tea and red wine.
They are usually subdivided according to their substituents present in flavanols (kaempferol, quercetin), anthocyanins, flavones, flavonones, and chalcones. These flavonoids display a remarkable array of biochemical and pharmacological actions, namely, anti-inflammatory, antioxidant, antiallergic, hepatoprotective, antithrombotic, antiviral, and anticarcinogenic activities [4]. Phytocompounds appear to play a vital role in defense mechanism against pathogens and predators and contribute to physiological functions of plant such as seed maturation and dormancy [5]. They are synthesized from phenyl propanoid and acetate derived precursors. Flavonoids are important for human beings due to their antioxidative and radical scavenging effects as well as their potential as estrogenic and anticancer activities [6]. In recent years, antibiotic resistance has become a global concern and this problem is more important in developing country because the infectious diseases are still an important cause of morbidity and mortality among humans. Plants rudely synthesize substances for their defense against insects, herbivores, and microorganisms 
[7]. Nowadays, multiple drug resistance is developed due to the indiscriminate use of drugs which are commonly used in the treatment of infectious diseases [8]. In addition to this problem, antibiotics are sometimes associated with adverse effect on the host including hypersensitivity, immune suppression, and allergic reaction [9]. Because of side effect and resistance that the pathogenic microorganism developed against antibiotics, recently much attention has been paid to extraction of biologically active compounds from plants. Plant based antimicrobials represent a vast updated source of medicine. Antibacterials of plant origin have enormous therapeutic potential. They are effective in the treatment of infectious diseases while simultaneously mitigating many of the side effects that are often associated with synthetic antimicrobials. The plant systematic classification is as follows. Kingdom-Plantae (Plants), Subkingdom-Tracheobionta (vascular plants), Division-Spermatophyte (seed plant), Subdivision-Angiosperm, Class-Dicotyledoneae, OrderCaryophyllales, Family-Portulacaceae, Genus-Portulaca, Species-oleracea. The plant P. oleracea L. (Purslane) is commonly known as Porsulane, an herbaceous weed. This plant is an annual succulent prostrate herb; stem is about $15.30 \mathrm{~cm}$ long, reddish, swollen at the nodes, and quite glabrous. Leaves are fresh, subsessile, $6.25 \mathrm{~mm}$ long, and alternate or subopposite. Flowers are sessile, axillary and terminal, few-flowered heads. Microscopic analysis of the leaf powder invariably shows spherical mineral crystals, sieve plants, tracheas with spiral, annular, and scalar form thickening, and vessels with bordered pits [10]. The present study deals with the isolation, purification and identification of flavonoid apigenin from $P$. oleracea $L$. (Figure 6) and also determines antibacterial activity on pathogenic bacteria.

\section{Materials and Methods}

2.1. Plant Material. Healthy aerial part of the plant of $P$. oleracea $L$. was collected from around Gulbarga University campus during the month of June 2012. The plant material was identified and authenticated from the Department of Botany, Gulbarga University, Gulbarga, Karnataka (India); voucher specimen (number HGUG-5013) has been deposited in herbarium of the same department.

2.2. Chemicals. Methanol, ethanol, ethyl acetate, petroleum ether, diethyl ether, $\mathrm{H}_{2} \mathrm{SO}_{4}$, chloroform, $\mathrm{HCl}, \mathrm{KOH}$, hexane, silica gel 60-120 mesh, tween 80, phosphate buffer saline, FCR reagent, all the chemicals, solvents, and reagents were analytical grade and were obtained from Hi media.

\subsection{Isolation of Total Flavonoids by Soxhlet Extraction Method.} Before extraction, $P$. oleracea $L$. was crushed into powder by versatile plant pulverize. The powder of the sample was degreased by soxhlet extractor with petroleum ether until the color of elute becomes colorless. The same powder sample was accurately weighed and placed in soxhlet extractor by adding $80 \mathrm{~mL}$ of ethanol: water $(70: 30)$ solvent, followed by the extraction for up to $5 \mathrm{~h}$, and then extract solution was concentrated. The extract was centrifuged at $11000 \mathrm{rpm}$ for $30 \mathrm{~min}$; supernatant was taken for further use [11].

2.4. Qualitative Test for Flavonoids. Two methods were used to determine the presence of flavonoids in the extract; $5 \mathrm{~mL}$ of dilute ammonia solution was added to a portion of total flavonoid extracts followed by addition of concentrated $\mathrm{H}_{2} \mathrm{SO}_{4}[12,13]$.

2.5. Determination of Total Flavonoid Content by UVSpectrophotometric Method. Firstly, $2 \mathrm{~mL}$ of the sample solution was accurately removed in a volumetric flask $(10 \mathrm{~mL})$ by adding $0.6 \mathrm{~mL}$ of $\mathrm{NaNO}_{2}$ (5\%) solution, shaking up, and then standing for $6 \mathrm{~min}$. Secondly, $0.5 \mathrm{~mL}$ of the $\mathrm{Al}\left(\mathrm{NO}_{3}\right)_{3}(10 \%)$ solution was added to the volumetric flask, shaken, and left to stand for $6 \mathrm{~min}$. Finally, $3.0 \mathrm{~mL}$ of the $\mathrm{NaOH}(4.3 \%)$ solution was added to the volumetric flask, followed by addition of water to the scale, shaken, and left to stand for $15 \mathrm{~min}$ before determination. Using the sample solution without coloration as reference solution and $500 \mathrm{~nm}$ as determination wavelength, the coloration method was used to determine the content of flavonoids in the sample by ultraviolet-visible detector [11].

2.6. Separation of Bioactive Compounds by PTLC. Glass plates $(20 \times 20 \mathrm{~cm})$ thickly coated $(0.4-0.5 \mathrm{~nm})$ with silica gel "G" $\left(45 \mathrm{~g} / 80 \mathrm{~mL}\right.$ water) and activated at $100^{\circ} \mathrm{C}$ for 30 minutes and cooled at room temperature were used for preparative thin layer chromatography (PTLC). The extract of flavonoid and standard apigenin were applied on plate and developed in n-butanol-water-acetic acid solvent system (mobile phase) $12: 2: 1 \mathrm{v} / \mathrm{v} / \mathrm{v}$. The chromatogram was air-dried and visualized under visible and UV light and also in iodine chamber. The spots were marked and the $R_{f}$ values were calculated [14].

\subsection{Separation of Flavonoids by Column Chromatography.} The total flavonoids which are isolated can be purified and separated by column chromatography separation method. The $45 \mathrm{~cm}$ length and $3 \mathrm{~cm}$ width of the column were used and it is filled with the slurry of silica gel- $\mathrm{H}$ of mesh size 60-120 $\mu$ (Hi media, Mumbai) to $1 / 3$ portion using $n$-hexane. Care should be taken to avoid the air bubble formation during column packing. Set the column by the solvent nhexane. $10 \mathrm{~g}$ of total flavonoid extract was bound with silica gel and loaded on the top of the column. The column was eluted with gradient solvent system of n-butanol-water-acetic acid system $12: 2: 1 \mathrm{v} / \mathrm{v} / \mathrm{v}$ until the color of the column is colorless.

\subsection{Physicochemical Structure Elucidation of Flavonoids by} Spectral Analysis. The pure compound of $P$. oleracea $L$. isolated was subjected to IR, NMR, LC-MS, and HPLC studies to obtain spectral data for the detection of functional group, number of protons, molecular mass of the compound, and purity, respectively [15]. 


\subsection{Antimicrobial Susceptibility Test}

2.9.1. Microorganisms. The bacterial strains employed in the current study were procured from Institute of Microbial Technology (IMTECH), Chandigarh (India), which include Pseudomonas aeruginosa (MTCC 424), Klebsiella pneumoniae (MTCC109), Salmonella typhimurium (MTCC98), Proteus mirabilis (MTCC425), and Enterobacter aerogenes (MTCC111). These species were originally isolated from clinical samples and identified by standard biochemical reactions.

2.9.2. Media. Nutrient broth (Hi Media M002) contains peptic digest of animal tissue $(5 \mathrm{~g} / \mathrm{L})$; yeast extract $(1.50 \mathrm{~g} / \mathrm{L})$ and beef extract $(1.5 \mathrm{~g} / \mathrm{L})$ were used for the growth of bacterial cultures. Antibiotic assay media No. 11 (Hi Media MM004) containing Peptic digest of Animal tissue (6g/L), Casein enzyme hydrolysed ( $4 \mathrm{~g} / \mathrm{L})$, Yeast extract $(1.50 \mathrm{~g} / \mathrm{L})$, Dextrose $(1.00 \mathrm{~g} / \mathrm{L})$. Agar $(15.00 \mathrm{~g} / \mathrm{L})$ was used for antibacterial activity.

2.9.3. Disc Diffusion Assay. The antimicrobial activity of apigenin was evaluated using a slightly modified agar disc diffusion method [16]. A bacterial culture grown for $18 \mathrm{~h}$ was serially diluted in $9 \mathrm{~mL}$ of $0.1 \%$ peptone to obtain $10^{5} \mathrm{CFU} / \mathrm{mL}$ and $100 \mu \mathrm{L}$ spread on the surface of Mueller Hinton (MH) agar in Petri plates. An aliquot $(10 \mu \mathrm{L})$ of apigenin was pipetted on a sterile paper disc (Whatman No. 1, $5.5 \mathrm{~mm}$ paper disc) on the agar surface. A disc impregnated with an aliquot $(10 \mu \mathrm{L})$ of streptomycin (Fluka, Switzerland) served as a positive control on the same plate. The plates were inverted and incubated for $18 \mathrm{~h}$ at $37^{\circ} \mathrm{C}$. Microbial inhibition was determined by measuring the diameter of the clear zone of inhibition of growth around each disc and recorded as diameter of inhibition zone (DIZ) in millimeter. All assays were performed using a randomized complete block design with two replicates.

2.9.4. Broth Dilution Assay. To determine the minimal inhibitory concentration (MIC), quantitative serial dilutions of apigenin were tested against five pathogenic bacterial strains with some modifications of the method described by Hufford and Clark $[17,18]$. Twofold serial dilution of apigenin was made with $\mathrm{MH}$ broth. After adding $20 \mu \mathrm{L}$ of apigenin to the first tube containing $1 \mathrm{~mL}$ of $\mathrm{MH}$ broth, serial transfers were made through to the fourth tube. A $0.5 \mathrm{~mL}$ aliquot $\left(5 \times 10^{5} \mathrm{CFU} / \mathrm{mL}\right)$ of test microorganism was added to each tube. A control tube contained $10 \mu \mathrm{L}$ of streptomycin in $\mathrm{MH}$ broth and microorganism was maintained. Tubes were subsequently incubated at $37^{\circ} \mathrm{C}$. The tubes were visually examined for the lowest concentration of apigenin that showed inhibition of microbial growth (indicated by a clear solution) after $24 \mathrm{~h}$ and $48 \mathrm{~h}$. The concentration in the lowest serial dilution of the apigenin at which growth did not occur on broth was recorded as the MIC. Finally, the $\mathrm{pH}$ value of the inoculated broth containing the MIC of apigenin was measured. Buffering of broth containing apigenin of $P$. oleracea $L$. was done using $\mathrm{NaOH}$ and subjected to broth dilution assay as the above to determine the MIC values.
TABLE 1: $R_{f}$ values of isolated bioactive compound and standard apigenin.

\begin{tabular}{|c|c|c|c|}
\hline Sl. number & Samples & $\begin{array}{l}\text { Solvent system } \\
(12: 2: 1 \mathrm{v} / \mathrm{v} / \mathrm{v})\end{array}$ & $R_{f}$ values \\
\hline 1 & $\begin{array}{l}\text { Standard } \\
\text { apigenin }\end{array}$ & $\begin{array}{c}\text { n-butanol-water-acetic } \\
\text { acid }\end{array}$ & 0.82 \\
\hline 2 & $\begin{array}{l}\text { Isolated } \\
\text { compound }\end{array}$ & $\begin{array}{c}\text { n-butanol-water-acetic } \\
\text { acid }\end{array}$ & 0.83 \\
\hline
\end{tabular}

\section{Results}

3.1. Qualitative Test for Flavonoids. The yellow coloration is observed after adding $\mathrm{H}_{2} \mathrm{SO}_{4}$ and it disappeared on standing. Few drops of $1 \%$ aluminum solution were added to a portion of flavonoid extract and again yellow coloration was observed; this indicates the presence of flavonoids.

3.2. Separation of Bioactive Compound by PTLC. When the developed plates were sprayed with $5 \%$ ethanol ferric chloride solution and placed in iodine chamber, they showed a spot which has a brownish color. The $R_{f}$ value (0.82) of apigenin isolated from the $P$. oleracea $L$. coincided with the $R_{f}$ value of standard apigenin. The results of PTLC $R_{f}$ values are shown in Table 1.

3.3. Determination of Total Flavonoid Content by UVSpectrophotometric Method. The basic structure of flavonoids was presented in Figure 1(a), and most of the flavonoids present in $P$. oleracea $L$. will be having $3^{\prime}, 4^{\prime}$-dihydroxysubstituted structure as shown in Figure 1(b). Flavonoids with $3^{\prime}, 4^{\prime}$-dihydroxy-substituted structure have shown a special color by reacting with the system of $\mathrm{NaNO}_{2}-\mathrm{Al}\left(\mathrm{NO}_{3}\right)_{3}$ $\mathrm{NaOH}$. The color reaction of flavonoids and chromogenic system is presented in Figure 1(c). This method is based on the reaction of aluminum ion with flavonoid at alkaline medium forming red chelates. By measuring the absorption of such red chelates, it is possible to determine the flavonoids.

3.4. Separation of Flavonoids by Column Chromatography. The total flavonoids of ethanol extract of $P$. oleracea $L$. of about $20 \mathrm{~g}$ were fractionated on a silica gel-H (60-120 mesh) column at room temperature and pressure $260 \mathrm{C}, 1$ bar. The total 32 fractions of $100 \mathrm{~mL}$ of each were collected. Each of the elutes was then crystallized with chloroform. The purified compound was subjected to its spectral analysis for structural elucidation.

\subsection{Physicochemical Structure Elucidation of Flavonoids by Spectral Analysis}

$F T-I R$. It can be resolved from the IR spectra that there are intensive bands in the $110-1000 \mathrm{~cm}^{-1}$ span that are characteristics of glycoside bonds and not bands of any sugar type. There are bonds of $\mathrm{V}_{\mathrm{CH}}$ vibration of $\mathrm{CH}_{2}$ group at approximately $2952 \mathrm{~cm}^{-1}$ and $2842 \mathrm{~cm}^{-1}$ and $\delta_{\mathrm{CH}}$ vibration at approximately $1451 \mathrm{~cm}^{-1}$. In the spectrum of $\mathrm{V}_{\mathrm{OH}}$ 
<smiles>CC(c1ccc(O)c(O)c1)C(c1ccc(O)cc1)C(C)C1CCc2ccccc2O1</smiles>

(a)<smiles>Oc1ccc(C2CCc3ccccc3O2)cc1O</smiles>

(b)

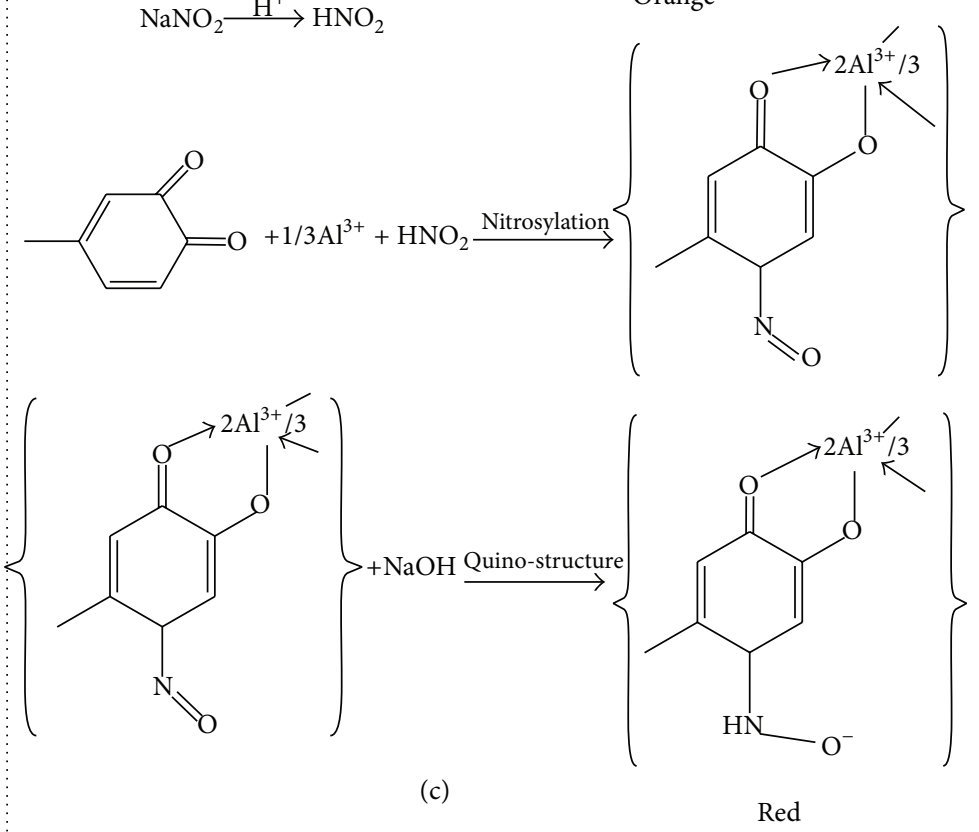

FIGURE 1: The color reaction of flavonoids and chromogenic system.

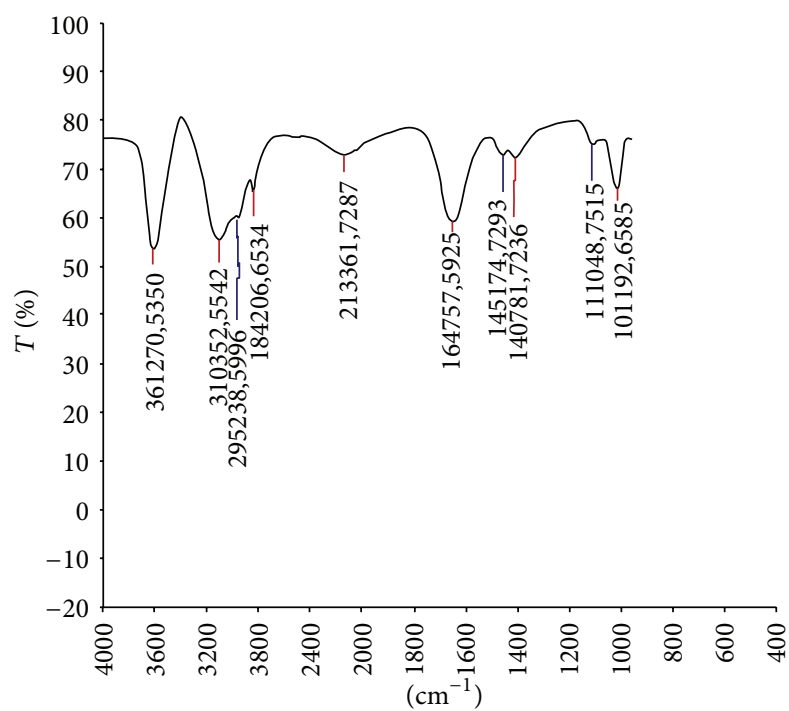

Figure 2: FT-IR spectrum of isolated compound apigenin from $P$. oleracea $L$.

vibration, there are bonds which are found at approximately $3612 \mathrm{~cm}^{-1}$ and others at approximately $3103 \mathrm{~cm}^{-1}$ that are most probably the result of $\mathrm{V}_{\mathrm{OH}}$ vibration of phenol $\mathrm{OH}$ groups. The intensive band at approximately $1647 \mathrm{~cm}^{-1}$ is most probably the result of $\mathrm{V}_{\mathrm{C}=\mathrm{O}}$ vibration of $\mathrm{C}=\mathrm{O}$ group from central heterocyclic ring, while the $\mathrm{V}_{\mathrm{C}-\mathrm{O}}$ vibration occurs at approximately $1110 \mathrm{~cm}^{-1}$. With these above spectral characteristics, it is indicated that the probable compound is apigenin (Figure 2).

${ }^{1} \mathrm{H}$ NMR. The ${ }^{1} \mathrm{H}$ NMR spectrum shows two singlets at 1.032 and $1.745 \delta(\mathrm{ppm})$ resonated to multiple of two protons of aromatic systems. The compound singlet peak at $\delta 7.99 \mathrm{ppm}\left({ }^{1} \mathrm{H}\right)$ was indicated for aromatic proton of phenolic hydroxyl. The identification of purified compound was further confirmed by ${ }^{1} \mathrm{H}$ spectrum data available in literature (Figure 3 ).

LC-MS. The mass spectrum that displayed a molecular ion $\left(\mathrm{M}^{+}\right)$peak at $m / z 269.19$ indicates the molecular weight of the compound corresponds to the molecular weight of apigenin and also corresponds to molecular formula $\mathrm{C}_{15} \mathrm{H}_{10} \mathrm{O}_{5}$. This further confirms that the structure of the isolated compound is apigenin (Figure 4).

HPLC. Chromatographic system and conditions are the LC system consisted of a Waters 600 solvent delivery pump, a Waters $2487 \mathrm{UV}$-visible spectrophotometric detector, an Empower system controller (Waters, USA), and HPLC analytical column (Diamonsil C 18 Column, $4.6 \times 200 \mathrm{~mm}$, i.d., $5 \mu \mathrm{M}$ particle size, Dikma) connected with a guard column filled with the same chromatographic stationary phase. The mobile phase for HPLC analysis consisting of Methanol- $0.2 \%$ Phosphoric acid (45:55, v/v) were filtered under reduced 


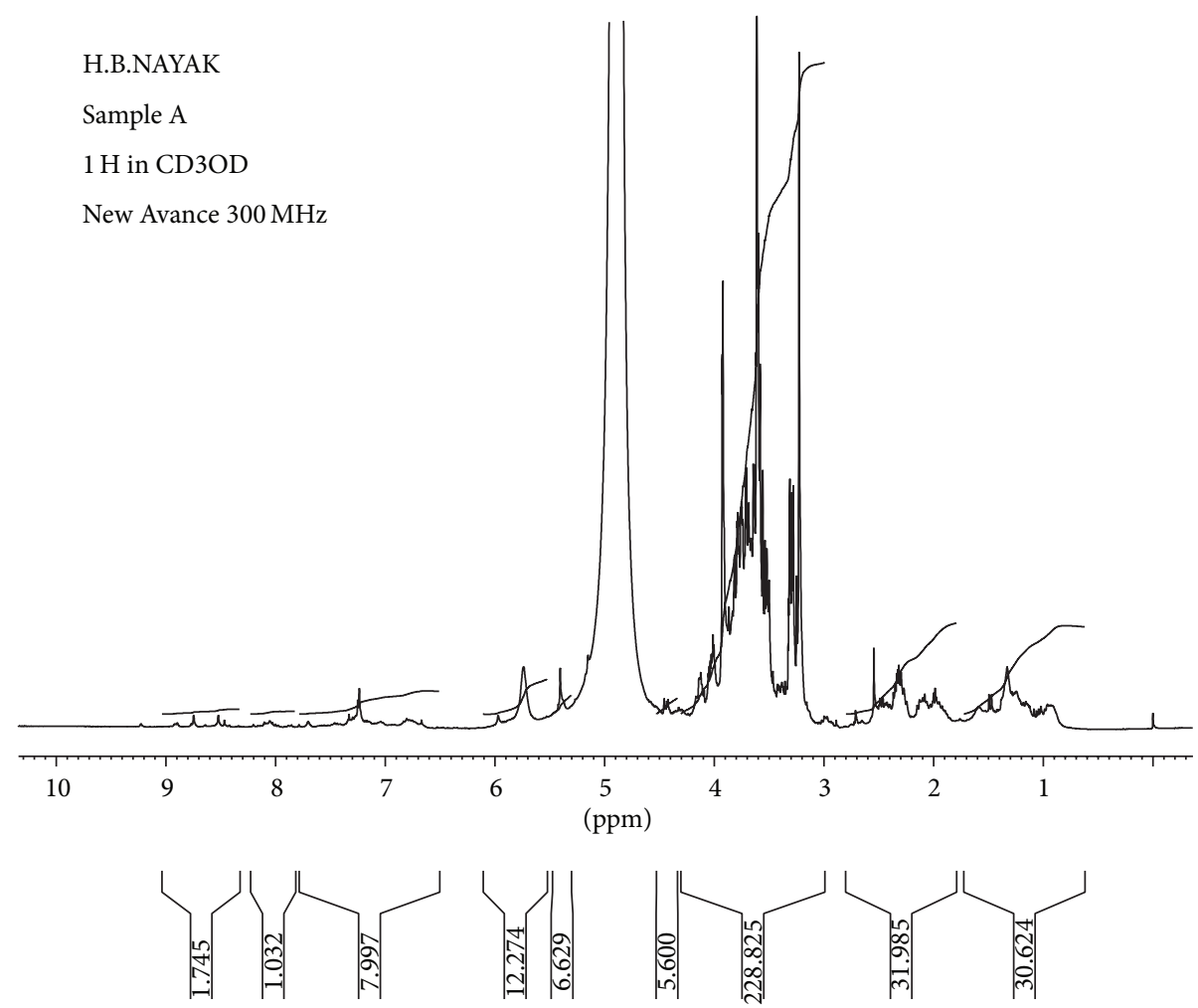

FIGURE 3: NMR spectrum of isolated compound apigenin from P. oleracea $L$.

pressure and degassed by ultrasonic before use. HPLC analysis with UV detection at $350 \mathrm{~nm}$ was performed at a flow rate of $1.0 \mathrm{~mL} / \mathrm{min}$. HPLC column temperature was $35^{\circ} \mathrm{C}$. The sample injection volume was $10 \mu \mathrm{L}$. The chromatographic peak of the apigenin is shown in the chromatogram in Figure 5.

\subsection{Antibacterial Susceptibility Test}

3.6.1. Disc Diffusion Assay. The mean diameters of the inhibition zones of apigenin against five pathogenic bacterial strains are shown in Table 2 . The results from disc diffusion assay showed that, among all bacterial strains, S. typhimurium $(17.36 \pm 0.18)$ and $P$. mirabilis $(19.12 \pm 0.01)$ have shown significant $(P<0.05)$ zone of inhibition, where remaining bacterial strains have shown less significant $(P<0.05)$ zone of inhibition when compared with control values $(14.56 \pm$ $0.21)$ and $(11.68 \pm 0.13)$, respectively.

3.6.2. Broth Dilution Assay. The results of the MIC values of apigenin of $P$. oleracea $L$. obtained at $24 \mathrm{~h}$ and $48 \mathrm{~h}$ are presented in Table 3. The present experimental data demonstrated that the apigenin of $P$. oleracea $L$. has displayed the antibacterial activity with MIC value $>4 \mathrm{mg} / \mathrm{mL}$ against all pathogenic bacterial strains which were subjected in the present study. The MIC values did not change after $48 \mathrm{~h}$ and also did not correlate well with the diameter of inhibition zones from the disc diffusion assay.

\section{Discussion}

The present study is conducted to extract flavonoids of $P$. oleracea $L$. by modified method of previous study [11]. This method of extraction was the best which had the highest content of quercetin, rutin, and apigenin, which are glycolflavones with a low impurity. More than 2000 flavonoids have been reported among woody and nonwoody plants [19]. PTLC, UV, and IR spectral studies have provided a new dimension to the chemistry of flavonoids to such an extent that their presence has become important in taxonomic study [20]. Presence of flavonoids has been reported in many plant species like Lycium barbarum, Passiflora palmer, Cassia angustifolia, and Jatropha curcas L. [21-24]. Apigenin has been reported in plant species like Bellis perennis L. and Adinandra nitida $[15,25]$. It is well known that apigenin has an antioxidant, anticarcinogenic, and spasmolytic activities and can reduce high blood pressure. That is why leaves of $P$. oleracea $L$. are a good source of apigenin, which can be added to food as a kind of functional ingredient or used as a vegetable, which have many beneficial effects on human health. It can also be used in medicine in standard forms of administration, such as capsules, tablets, and oral suspensions [26]. The extraction, isolation, purification, and characterization of this compound from $P$. oleracea $L$. and structural elucidation of this compound have been studied. In the present study, the results of qualitative tests (specific for flavonoids) of flavonoids can be compared with the results of previous studies conducted on phytotoxicity and antimicrobial activities of flavonoids in Ocimum gratissimum [27]. 


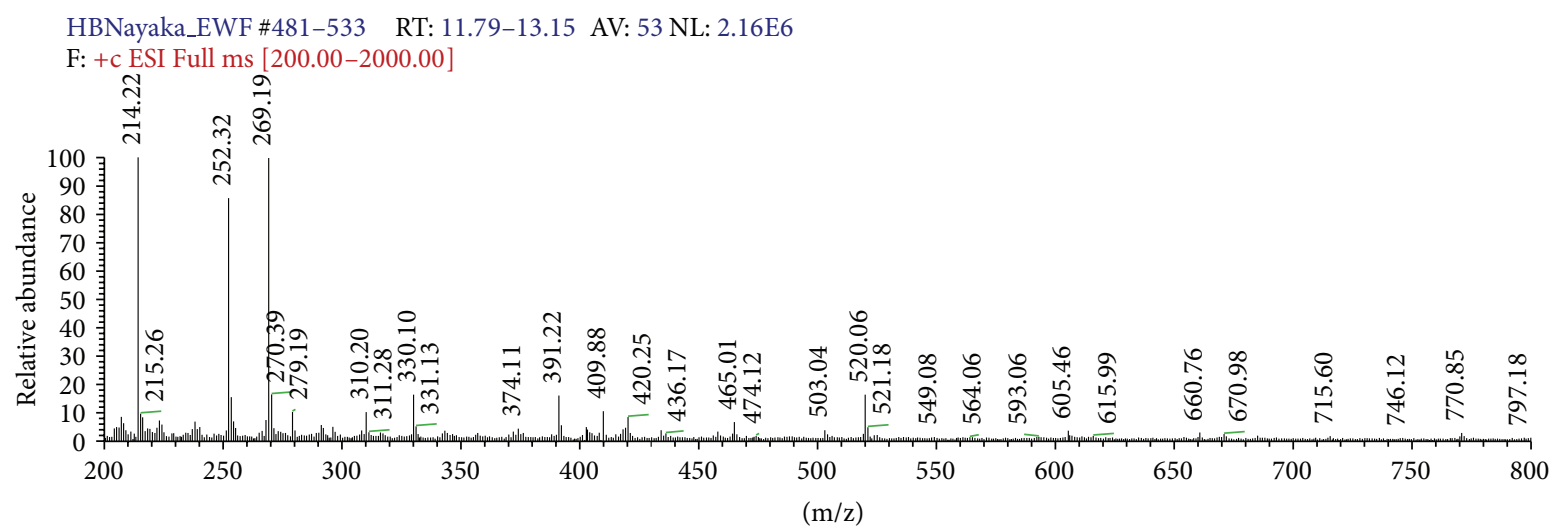

FIGURE 4: LC-MS spectrum of isolated compound apigenin from P. oleracea L.

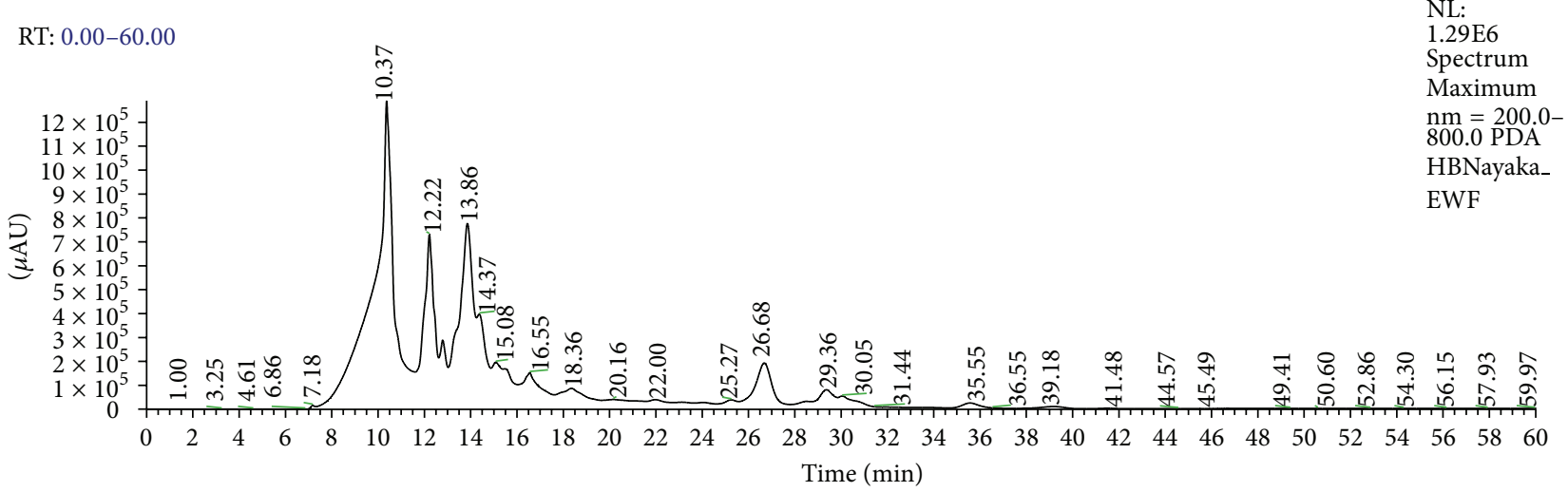

FIGURE 5: HPLC chromatogram of isolated compound apigenin from P. oleracea $L$.

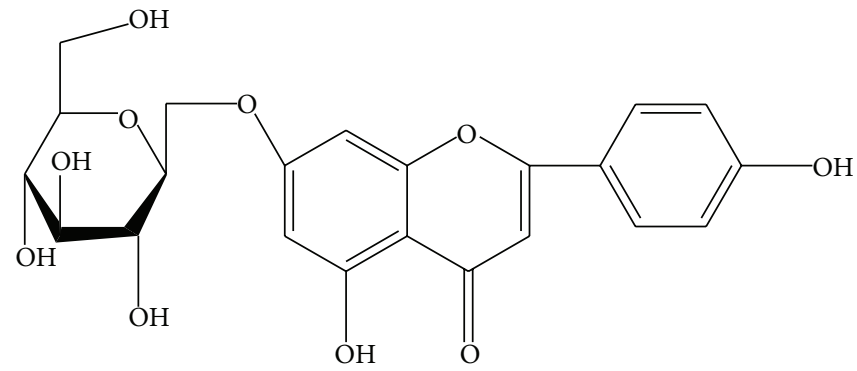

Figure 6: Structure of flavonoid apigenin isolated from P. oleracea $L$.

TABLE 2: Antimicrobial activity (diameter of inhibition zone) of apigenin of P. oleracea L. on pathogenic bacteria.

\begin{tabular}{lccc}
\hline Bacterial strains & MTCC number & \multicolumn{2}{c}{ Diameter of inhibition zone $(\mathrm{mm})$} \\
\hline P. aeruginosa & MTCC424 & Streptomycin as control $(10 \mu \mathrm{L})$ & $17.42 \pm 0.54$ \\
K. pneumoniae & MTCC109 & $21.33 \pm 0.33$ & $12.24 \pm 0.41$ \\
S. typhimurium & MTCC98 & $14.56 \pm 0.21$ & $10.52 \pm 0.38$ \\
P. mirabilis & MTCC425 & $11.68 \pm 0.13$ & $17.36 \pm 0.18^{* *}$ \\
E. aerogenes & MTCC111 & $19.66 \pm 0.27$ & $12 \pm 0.01^{* * *}$ \\
\hline
\end{tabular}

${ }^{* *}$ Moderate significant; ${ }^{* * *}$ most significant at $P \leq 0.05$. Values are expressed as mean $\pm \mathrm{SD}$. 
TABLE 3: Antibacterial activity (minimum inhibition concentration after $24 \mathrm{~h}$ and $48 \mathrm{~h} ; \mathrm{mg} / \mathrm{mL}$ ) of apigenin of P. oleracea $\mathrm{L}$.

\begin{tabular}{lcc}
\hline Bacterial strains & MTCC number & Apigenin of $P$. oleracea $\mathrm{L}$. \\
\hline P. aeruginosa & MTCC424 & $>4$ \\
K. pneumoniae & MTCC109 & $>4$ \\
S. typhimurium & MTCC98 & $>4$ \\
P. mirabilis & MTCC425 & $>4$ \\
E. aerogenes & MTCC111 & $>4$ \\
\hline
\end{tabular}

In the present study, the flavonoids contents are determined by $\mathrm{NaNO}_{2}-\mathrm{Al}\left(\mathrm{NO}_{3}\right)_{3}-\mathrm{NaOH}$ colorimetric method. The result indicates that the $P$. oleracea $L$. has contained more flavonoids. Basic structure of flavonoids was presented in Figure 1(a), and most of the flavonoids in P. oleracea L. have $3^{\prime}, 4^{\prime}$-dihydroxysubstituted structure as shown in Figure 1(b). Flavonoids with $3^{\prime}, 4^{\prime}$-dihydroxy-substituted structure can show special color by reacting with the system of $\mathrm{NaNO}_{2}-\mathrm{Al}\left(\mathrm{NO}_{3}\right)_{3}-\mathrm{NaOH}$. The color reaction of flavonoids and chromogenic system is presented in Figure 1. As shown in Figure 1, this method is based on the reaction of aluminum ion with flavonoid at alkaline medium forming red chelates. By measuring the absorption of such red chelates, it is possible to determine the flavonoids [11]. The structural elucidation of apigenin is possible because of spectral data obtained. In the present study the IR spectrum has vibration bonds at $3612 \mathrm{~cm}^{-1}$ and $3103 \mathrm{~cm}^{-1}$ approximate, which are most probably the result of $\mathrm{V}_{\mathrm{OH}}$ vibration of phenol $\mathrm{OH}$ groups. The intensive band at approximately $1647 \mathrm{~cm}^{-1}$ is most probably the result of $\mathrm{V}_{\mathrm{C}=\mathrm{O}}$ vibration of $\mathrm{C}=\mathrm{O}$ group from central heterocyclic ring. Similar results were obtained in the study conducted for extraction of apigenin from the sage(Salvia officinalis L.) from Jordan [14]. The LC-MS spectrum that displayed the molecular ion $\left(\mathrm{M}^{+}\right)$peak at $m / z 269.19$ in the present study indicates the molecular weight of the apigenin compound; this result is similar to the LC-MS spectrum study conducted by [15] in the plant Adinandra nitida. For the confirmation of purity, the compound is again subjected to HPLC analysis; the results of HPLC chromatogram showed single base peak at $10.3 \mathrm{AU}$; it is again conformed with the compound apigenin. Nowadays, multiple drug resistance developed due to the indiscriminate use of drugs commonly used in the treatment of infectious diseases. Unfortunately, bacteria have genetic ability to transmit and acquire resistance to drugs and chemicals [28]. Based on the results of antibacterial studies shown in Table 2, the apigenin had an antibacterial activity more significant on S. typhimurium and P. mirabilis when compared with control group. This may be due to the chemical nature of apigenin, cell membrane permeability, and other factors. In general, composition of the inhibition zones diameter showed that apigenin was more effective against both gram positive and gram negative bacteria. This difference may be due to several possible reasons such as permeability barrier provided by the presence of cell wall with multilayer structure in gram negative bacteria or the membrane accumulation mechanism or presence of enzymes in periplasmic space which are able to break down foreign molecules introduced from outside [29]. The MIC value (Table 3) for apigenin isolated from $P$. oleracea $L$. against all the pathogenic bacterial strains which were subjected in the present study was $>4 \mathrm{mg} / \mathrm{mL}$; it is reported that, for bacterial antimicrobials, the MIC was often near or Aquila values [30].

\section{Conclusion}

The flavonoids of $P$. olerace $L$. were isolated by employing the extraction with ethanol: water $(70: 30)$ solution. The result of qualitative test which is specific for flavonoids confirmed that the isolated compound was flavonoid. The results of PTLC, HPLC, LC-MS, FT-IR, and NMR further confirmed that the compound is apigenin. The antibacterial results of the present study will suggest that the isolated apigenin bioactive compound is also having potential antibacterial activity indicating that it can be used for development of antibacterial drugs for the treatment of diseases associated with these pathogenic bacteria.

\section{Conflict of Interests}

The authors declare that there is no conflict of interests regarding the publication of this paper.

\section{Acknowledgments}

The authors are thankful to University Grant Commission New Delhi (India) for providing financial support to carry out this research work under the scheme of Rajeev Gandhi National Fellowship (UGC-RGNF). The authors are also thankful to Gulbarga University, Gulbarga, for providing all the necessary facilities to carry out this research.

\section{References}

[1] M. C. Gordon and J. N. David, "Natural product drug discovery in the next millennium," Pharmaceutical Biology, vol. 39, pp. 8$17,2001$.

[2] M. Wink, "Introduction: biochemistry, role and biotechnology of secondary products," in Biochemistry of Secondary Product Metabolism, M. Wink, Ed., pp. 1-16, CRC Press, Boca Ratom, Fla, USA, 1999.

[3] J. B. Harborne, "Nature, distribution and function of plant flavonoids," Progress in Clinical and Biological Research, vol. 213, pp. 15-24, 1986.

[4] E. Middleton and C. Kandaswami, "The impact of plant flavonoids on mammalian biology: implications for immunity, inflammation and cancer, in the flavonoids," in Advances in Research Science, I. R. Harborne, Ed., pp. 619-645, Chapman and Hall, London, UK, 1993.

[5] B. Winkel-Shirley, "Biosynthesis of flavonoids and effects of stress," Current Opinion in Plant Biology, vol. 5, no. 3, pp. 218223, 2002.

[6] K. Springob and K. Saito, "Metabolic engineering of plant secondary metabolism: promising approach to the production of pharmaceuticals," Science and Culture, vol. 68, pp. 76-85, 2002 . 
[7] O. O. Aboaba, S. I. Smith, and F. O. Olude, "Antibacterial effect of edible plant extract on Escherichia coli 0157, H7, part," Pakistan Journal of Nutrition, vol. 5, no. 4, pp. 325-327, 2006.

[8] J. Davies, "Inactivation of antibiotics and the dissemination of resistance genes," Science, vol. 264, no. 5157, pp. 375-382, 1994.

[9] I. Ahmad, Z. Mehmood, and F. Mohammad, "Screening of some Indian medicinal plants for their antimicrobial properties," Journal of Ethnopharmacology, vol. 62, no. 2, pp. 183-193, 1998.

[10] G. Banerjee and A. Mukherjee, "Antibacterial activity of a common weed, Portulaca oleracea L," Geobios, vol. 30, pp. 143144, 2003.

[11] H. Zhu, Y. Wang, Y. Liu, Y. Xia, and T. Tang, "Analysis of flavonoids in Portulaca oleracea L. by UV-vis spectrophotometry with comparative study on different extraction technologies," Food Analytical Methods, vol. 3, no. 2, pp. 90-97, 2010.

[12] A. Sofowara, Medicinal Plants and Traditional Medicine in Africa, Spectrum Books, Ibadan, Nigeria, 1993.

[13] J. B. Harbone, Phytochemical Methods, pp. 49-188, Chapman and Hall, London, UK, 1973.

[14] D. Sinisa, C. Milorad, and A. Salameh, "The extraction of apigenin and luteolinfrom the sage Salvia officinalis $L$. from Jordan," The Scientific Journal Factauniversities, Series: Working and Living Environmental Protection, vol. 1, no. 5, pp. 87-93, 2000.

[15] B. Liu, Z. Ning, J. Goo, and K. Xu, "Preparing apigenin from leaves of Adinandranitida," Food Technology and Biotechnology, vol. 46, no. 1, pp. 111-115, 2008.

[16] A. L. Barry, The Antimicrobial Suseptabalitytest: Principale and Practices, Lea and Febiger, Philadelphia, Pa, USA, 1976.

[17] C. D. Hufford and A. M. Clark, "Discovery and development of new drugs for systemic opportunistic infection," in Studyies in Natural Products Chemistry, A.-U. Rahman, Ed., pp. 421-452, Elsevier, 1988.

[18] N. S. Weerakkody, N. Caffin, M. S. Turner, and G. A. Dykes, "In vitro antimicrobial activity of less-utilized spice and herb extracts against selected food-borne bacteria," Food Control, vol. 21, no. 10, pp. 1408-1414, 2010.

[19] J. B. Harborne, "Plant phenolic," in Secondary Plant Products, E. A. Bell and B. V. Charlewood, Eds., p. 320, Springer, Berlin, Germany, 1980.

[20] E. B. Smith, Prospective in Phytochemistry, J. B. Harborne and T. Swain, Eds., Academic Press, London, UK, 1969.

[21] M. L. Harsh, T. N. Nag, and S. Jain, "Arid zone plants of Rajasthan a source of Antimicrobials," Communication in Physiological Ecology, vol. 8, pp. 129-131, 1983.

[22] A. Ulubelen, T. J. Mabry, G. Dellamonica, and J. Chopin, "Flavonoids from Passiflora palmeri," Journal of Natural Products, vol. 47, no. 2, pp. 384-385, 1984.

[23] A. Goswami and A. Reddi, "Antimicrobial activity of flavonoids of medicinallyimportant plant Cassia angustifolia in vivo and in vitro," Journal of Phytological Research, vol. 17, pp. 179-181, 2004.

[24] S. Saxena, R. Sharma, S. Rajore, and A. Batra, "Isolation and identification of flavonoid, "Vitexin" from Jatrophacurcas L," Journal of Plant Sciences Research, vol. 21, pp. 116-117, 2005.

[25] J. Nazaruk and J. Gudej, "Apigenin glycosides from the flowers of Bellis perennis L," Acta Poloniae Pharmaceutica-Drug Research, vol. 57, no. 2, pp. 129-130, 2000.

[26] C. Engelmann, E. Blot, Y. Panis et al., "Apigenin-strong cytostatic and anti-angiogenic action in vitro contrasted by lack of efficacy in vivo," Phytomedicine, vol. 9, no. 6, pp. 489-495, 2002.
[27] O. Ighodaro, A. S. Macdonald, and A. O. Oludare, "Phytotoxic and anti-microbial activities of flavonoids in Ocimum gratissimum," Life Science Journal, vol. 7, no. 3, pp. 45-48, 2010.

[28] G. G. F. Nascimento, J. Locatelli, P. C. Freitas, and G. L. Silva, "Antibacterial activity of plant extracts and phytochemicals on antibiotic-resistant bacteria," Brazilian Journal of Microbiology, vol. 31, no. 4, pp. 247-256, 2000.

[29] J. Parekh and S. Chanda, "Antibacterial and phytochemical studies on twelve species of Indian medicinal plants," African Journal of Biomedical Research, vol. 10, pp. 175-181, 2007.

[30] K. D. Reuben, F. I. Abdulrahman, J. C. Akan, H. Usman, O. A. Sodipo, and G. O. Egwu, "Phytochemical screening and in vitro antimicrobial investigation of the Methanolic extract of Croton zambesicus muell ARG. stem bark," European Journal of Scientific Research, vol. 23, no. 1, pp. 134-140, 2008. 

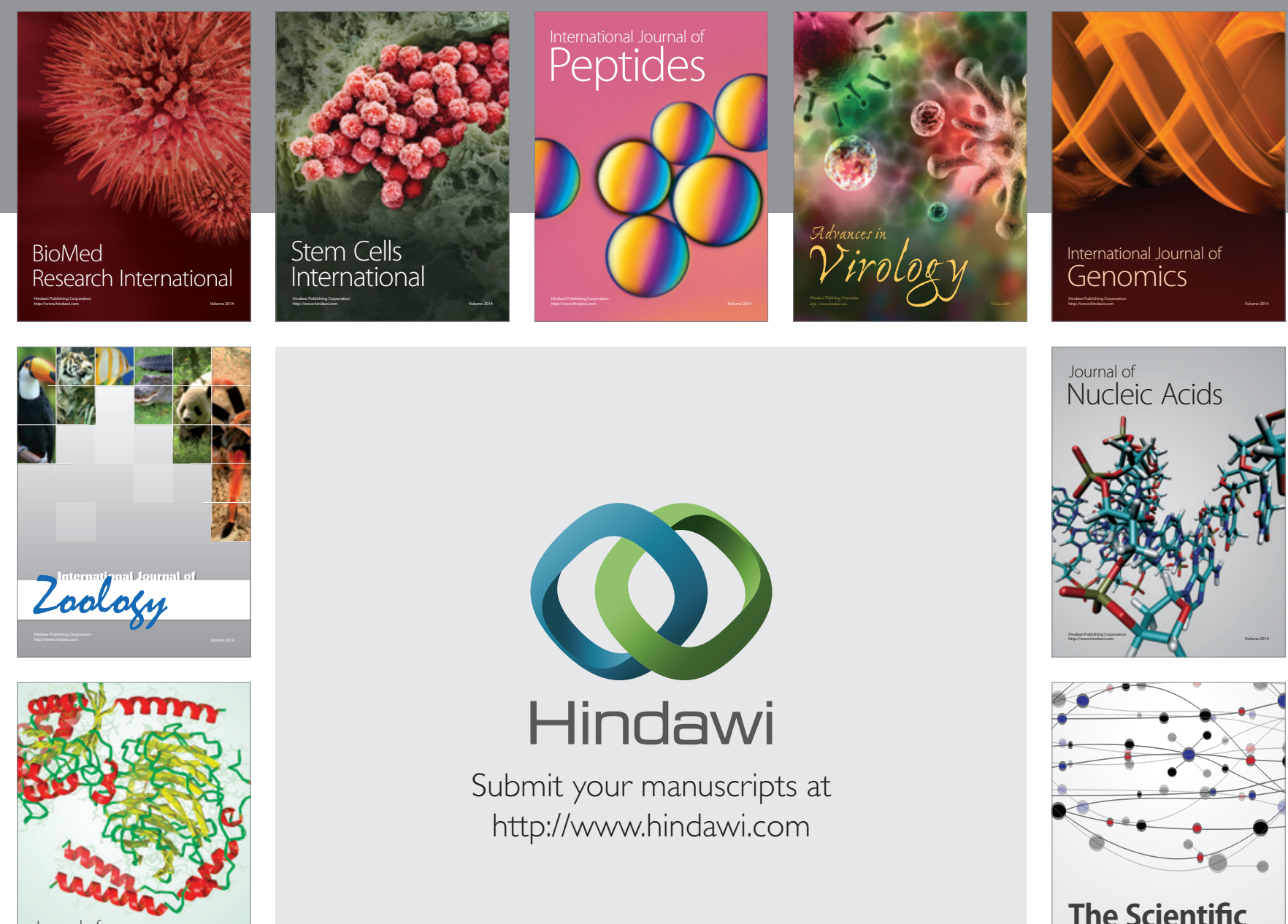

Submit your manuscripts at

http://www.hindawi.com

Journal of
Signal Transduction
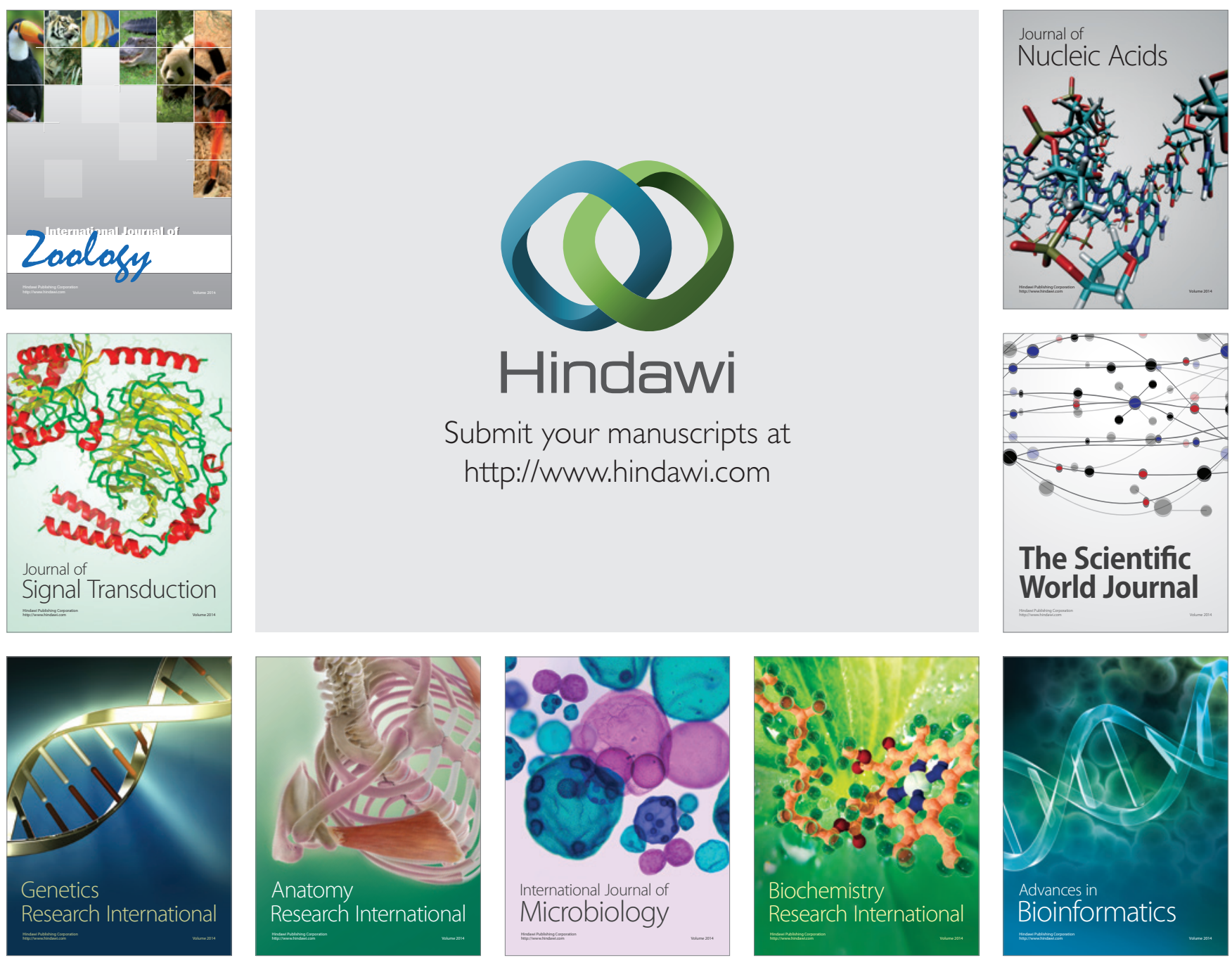

The Scientific World Journal
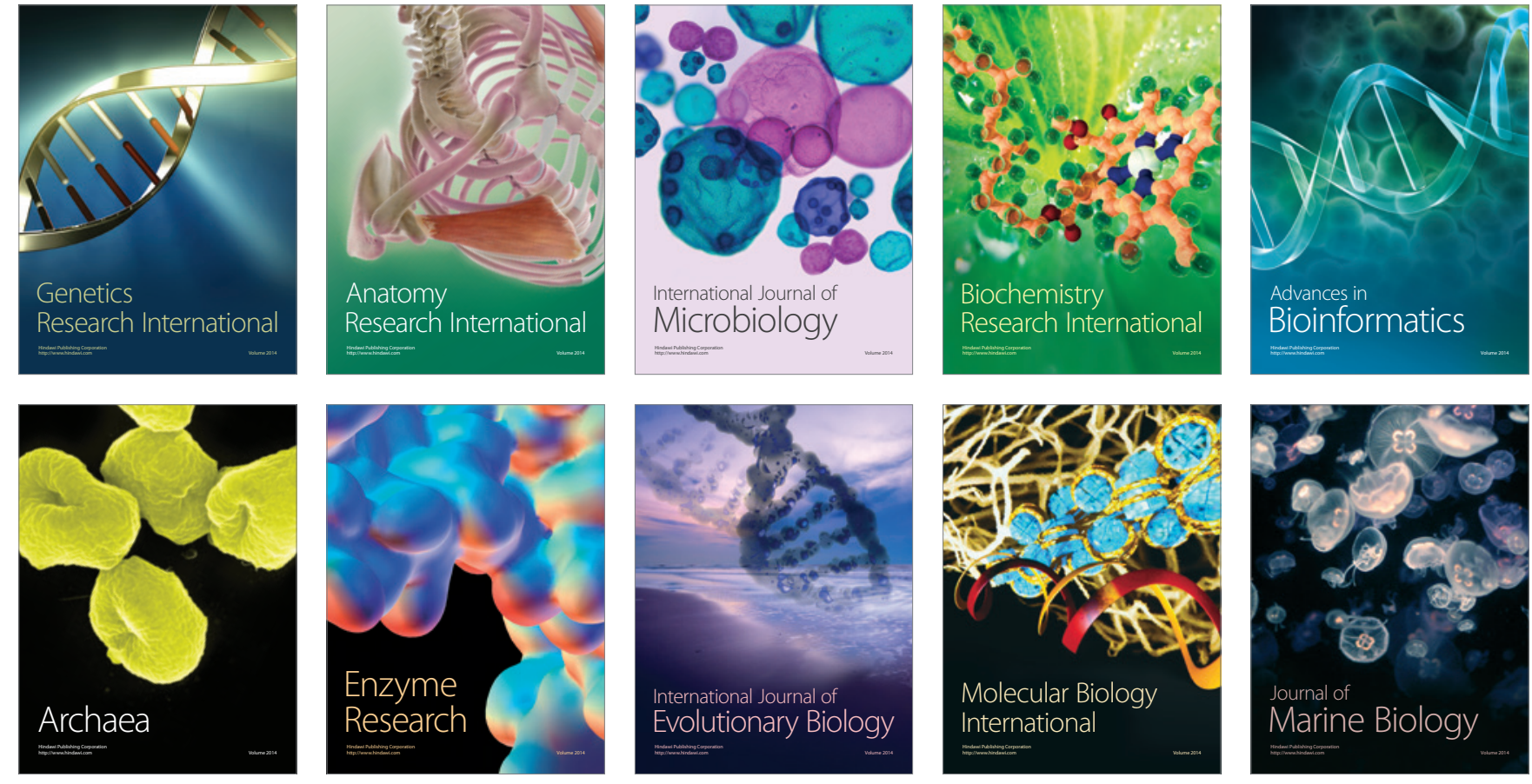